\title{
Aesthetics and Transcendence in the Arab Uprisings
}

\author{
Ebrahim Moosa
}

Duke University, Durham, N.C.

\begin{abstract}
Politics is regarded as a science for it tells us what to do, when it deals with measurable concepts. But politics is also an art-a form of practice, telling us how and when to do things. Lest we forget, the arts of persuasion and inspiration are part of politics. And, every art also produces an aesthetic. By aesthetics I mean, the ways by which we think about art: recall, art is what we do and how we do things. Those things and acts that become visible when we do and produce certain actions-jubilation, conversations, speeches, greetings, protests, banners, deaths, wounds and other expressions-all constitute the means by which thought becomes visible, effective, and sensible. These forms and visible expressions of the sensible constitute the aesthetics of politics. Only the patient will know where the momentum for change in the Arab world is heading. But, if the outcome of the Arab uprisings is unclear, then there is one certainty: the people have changed the order of the sensible. Thanks to peaceful protests in the face of regime brutality, tens of millions of people have performed change in myriads of expressions: aesthetics. Their feelings have cumulatively changed, and how people feel about governance is ultimately what politics is all about.
\end{abstract}

\section{Keywords}

politics; aesthetics; non-violence; bio-politics

Only the patient will know where the momentum for change in the Arab world is heading. Why? Firstly, one should welcome change but be cautious of its ends. Secondly, Longfellow famously reminded us: "art is long, time is fleeting." Politics is of course regarded as a science for it tells us what to do, when it deals with measurable concepts. But politics is also an art-a form of practice, telling us how and when to do things. Lest we forget, the arts of persuasion and inspiration are part of politics.

And, every art also produces an aesthetic. By aesthetics I mean, the wayscall it modes or regimes-by which we think about art: recall, art is what we do and how we do things. Those things and acts that become visible when we 
do and produce certain actions_-jubilation, conversations, speeches, greetings, protests, banners, deaths, wounds and other expressions-all constitute the means by which thought becomes visible and effective. ${ }^{1}$ For the Polish writer Czeslaw Miłosz, pleasures of an aesthetic nature occur in the "stream of life" which springs from "the feeling of potentiality, of constant unexpectedness, of a mystery one ever pursues." 2 These forms and visible expressions of the sensible constitute the aesthetics of politics. If the outcome of the Arab uprisings is unclear, then there is one certainty: the people have changed the order of the sensible. Thanks to peaceful protests in the face of regime brutality, tens of millions of people have performed change in myriads of expressions: aesthetics. Their feelings have cumulatively changed. We often forget that how people feel about governance is ultimately what politics is all about.

In Tunisia, Egypt, Libya, Yemen, Bahrain and Syria in the spring of 2011and a few years earlier in Iran-people stopped fearing their brutal governments and the lethal security and torture apparatuses they commanded. It did not matter if the influential international friends and allies of their tormentors rooted for their success or wished them to fail (although most democratic societies thankfully supported the uprisings). Yet, the politics in countries that rid themselves of tyrants in the Middle East remain a work-in-progress. If one is wed to the idea of revolution, then it is perhaps better to call them revolutions in a slow cooker. Interestingly, this is also the view of the outspoken Egyptian novelist, Sonallah Ibrahim. ${ }^{3}$

Without detracting from the bravery, courage and sacrifice of millions, I can only agree with Mouin Rabbani that as "the Arab Spring continues to flower and wilt, and flower again and wilt again, there will be simply no way of knowing where things are likely to stand six months in the future." ${ }^{4}$ Only the very brave can risk charting trajectories and make predictions where this will end, while the fainthearted take refuge in literature and the past as sources of inspiration and guidance for the present.

If we want to know why these events erupted, and why it took everyone by surprise, then the Czech writer Milan Kundera reminds us what we had

\footnotetext{
1) Jacques Rancière, The Politics of Aesthetics: The Distribution of the Sensible, trans. Gabriel Rockhill (London \& New York: Continuum, 2004), 10.

2) Miłosz, Czesław, The Captive Mind. trans. Jane Zielonko (New York: Vintage Books, 1981) 65-66.

3) Elliott Colla, “The Imagination as Transitive Act: An Interview with Sonallah Ibrahim," Jadaliyya, 6 June 2011, http://tinyurl.com/6zwrfuh (accessed 7 July 2011).

4) Mouin Rabbani, "A Long Season of Change Ahead for Every Arab Nation," Jadaliyya, 20 June 2011, http://tinyurl.com/6av2qy5 (accessed 7 July 2011).
} 
forgotten. "The struggle of man against power," Kundera said a while ago, "is the struggle of memory against forgetting." The daily grind against brutality is a politics-a struggle, not very different from our struggle to remember the quotidian things in life. Both tasks are endless and futile, yet paradoxically, indispensable.

What we do know for certain, however, is that the power of the tyrants has turned out to be false: their weakness was camouflaged as power, but in an ugly display of brutality. In the previous century, Muhammad Iqbal, the poetphilosopher of pre-partition India, rightfully identified impotence and the inability to take control of one's self and one's destiny as a "crime". How? Terror and tyranny, two sins prevalent in some quarters of the Middle East today, would surely count as signs of impotence in Iqbal's view. Iqbal chaffed at powerlessness and favored power in the constructive sense, virtues that made growth and self-realization possible. In an unforgettable line, Iqbal presciently said: "For the crime of impotence, only sudden death is a fitting punishment." The terror mastermind, Osama bin Laden, was only superficially different from former presidents Mubarak and Ben Ali, as well as other tyrants in the region. What both the tyrants and terrorists shared was a weakness, shrouded in brutality. And they can all now attest to Iqbal's wisdom, both literally and figuratively, whether their fall from grace or death was a sign of strength or impotence.

Taking their destiny into their own hands was to follow an Iqbalian imperative. The use of non-violence was certainly the game-changer in these uprisings, where sheer people-power undid the autocratic regimes. In the past, Islamist and radical leftists groups frequently used violence or the threat thereof to resist tyranny. But often the use of violence gave totalitarian regimes the justification to lethally crush them with the consent of the silent majority, as well as the world community. However, such repression did not address the underlying grievances and their causes. Although large groups of people caved in to the regimes' demands of obedience for decades, the struggle on the part of committed groups continued relentlessly. But the odds were stacked against the agents of change. Does all this suggest that a Black Swan event made these uprisings possible?

Normally swans are white, but oddly enough a black swan was sighted in Australia that broke the pattern. The Lebanese American social scientist,

5) Milan Kundera, The Book of Laughter and Forgetting (Harmondsworth \& New York: Penguin Books, 1981), 4.

6) Muhammad Iqbal, Āsān Kulliyāt-i Iqbāl (Urdū) (Islamabad: Alhamra Publishing, 2000), 614. 
Nassim Nicholas Taleb, regards almost all major scientific discoveries, historical events, and artistic accomplishments as "black swans". ${ }^{7}$ These are events, in his view, that are undirected and unpredicted. Among his prime examples of Black Swan events include the emergence of the Internet, the personal computer, World War I, and the September 11 attacks. So even if the uprisings ultimately go nowhere-despite our current hope that they will have productive ends - the very fact that the efforts of millions toppled ruthless dictators through peaceful means does indeed qualify as a Black Swan event, or a series of such events.

In fact, non-violent protest in the Arab world during the spring of 2011 is, in itself, a Black Swan event. Non-violent protest has never had an impact on such a large scale; powerful enough to set an entire region alight. ${ }^{8}$ A Black Swan event normally has three characteristics. First, it is an outlier, as it lies outside the realm of regular expectations, because nothing in the past could convincingly point to its possibility. Second, it carries an extreme impact. Third, despite its outlier status, there is something in our nature that enables us to construe explanations after the fact as to why it occurred, and thus making it more explainable, predictable and believable. That a marginal Arab country, Tunisia, and its citizens could inspire the masses in a neighboring country like Egypt, the capital of the Arab world, and then shake its establishment might once have sounded preposterous, but no longer. Indeed, it might have been easier to believe that the Egyptian pyramids in Giza had magically transported themselves to Gaza in the Palestinian territories, than entertain the idea that Mubarak could be shoved off his throne!

The relentless murder of Syrian citizens by the Assads' notorious mukhabarat (security services), under both père and now fils, continues. As this drama unfolds, the thought of a long-dead poet keeps haunting me-a thought precipitated by the actions of Syrian security forces in the town of Jisr al-Shoughour. This town is near another one, mentioned in the Arabic media, called Maarrat al-Numan, and recent television footage has shown refugees fleeing from Maarrat al-Numan to camps inside Turkey. For the world's media, this is just another Syrian town ravaged by the brutality of the Assad regime.

\footnotetext{
7) Nassim Taleb, The Black Swan: The Impact of the Highly Improbable (New York: Random House, 2007).

8) At the risk of contradicting myself, toppling regimes was thinkable in light of what happened in Iran more than three decades ago in 1979, which was also at the time viewed as a Black Swan event.
} 
Yet more than a millennium ago, one of the bravest voices in Arabic literature was born there, a man called Abul Ala al-Maarri (b. 973-d. 1058). Blinded at an early age, Ma arri was a courageous social commentator. Unafraid to speak his mind on politics, and voice his skepticism of religious leaders, he was a humanist par excellence. Not only was he a life-long vegetarian, but also detested all violence to the point of commiserating with insects and animals on their collective fate at the hands of humans. So when people all over the region resorted to non-violent means of resistance, they took a page out of Maarri's playbook. In Spark of Tinder, his most remarkable collection of poetry, he writes: "I was fierce, but when I found my ferocity futile/I was sobered and so I filled time with integrity." On reading Maarri, I could not suppress the thought that in the aesthetics of their politics, the Arab protesters had indeed filled the world with integrity, sobriety and compassion. In doing so, they shamed their tormentors.

What completely undermined the sense of 'normality' that Arab dictators exhibited was the sobriety with which people made demands and claimed their rights. The Mubaraks, the Ben Alis, the Salehs and the Assads were outwitted by the non-violent and peaceful nature of the protests. All they could do was to retaliate with what they knew best-namely, with force-batons, bullets and beatings. So they manufactured violence in order to discredit their opponents. They could not have been more deluded in believing that their writ of governance was still in force (i.e., to counter ferocity with ferocity, an eye for an eye). This time there was no ferocity to stamp out. By which right of justice or governance can one punish non-violent protesters in Tunis, Cairo, Hama and Damascus? The people defied the rules of the game. How does one destroy integrity?

Yet, I will concede a revolution did take place; an aesthetic revolution occurred. The French political theorist, Jacques Rancière, describes an aesthetic revolution as one that "rearranges the rules of the game by making two things interdependent." ${ }^{\prime}$ Firstly, it blurs the borders between the logic of facts and the logic of fictions and, secondly, it introduces a new mode of rationality, a new way of thinking about history.

The sensible or the aesthetics was not rearranged in January of 2011, when the tyrants fell in Tunis and Cairo. The alteration of the sensible occurred over decades, and like dynamite, comes in small packages and almost undetected. For decades, intellectuals and thinkers, writers, artists, painters, calligraphers,

9) Rancière, The Politics of Aesthetics, 36. 
actors, playwrights, and a range of performers have slowly and gradually changed the order of the sensible. Often governments censored them. On other occasions, uncivil elements in civil society objected to the art and ideas of thinkers at great cost to the artists. I speak of the public reproach many artists and writers suffered, forcing several to go into exile or seek internal exile by lying low in understandable fear to fight another day. An attacker seriously wounded Najib Mahfouz, Egypt's only Nobel laureate for literature. Scores of writers and authors were framed for treason and imprisoned, or faced an even worse fate. I think of the late Nasr Hamid Abu Zayd, a Cairo University professor whose writing was subjected to a heresy trial that declared him a nonMuslim on account of his scholarly views on Islam and the interpretation of the Qur'an.

Among those people who made a difference is Huda Lutfi. As a Cairo-based artist and former professor, she is among the many who, a few decades ago, began exploring change through art. ${ }^{10}$ Lutfi is a consummate bricoleur. She goes out into the city and collects images and objects, and then gives new meaning to them in her carefully constructed composition. In her work on the feminine body, culture and taboos restricted her explorations. But in order to explore the limitations of expression in the feminine body she turned to the male body. In an exhibition called In Making a Man out of Him, she presents masculinity as a continuous and changing performance of power versus vulnerability. Through new conceptual departures, Lutfi identifies the sociocultural forces that define masculine identity against feminine identity. Starting off as a non-mainstream artist, Lutfi has now captured a great deal of attention with her work that transforms the sensible and the thinkable.

Novelists, too, have helped to alter the sensible. Alaa al-Aswany in The Yacoubian Building talks about the three taboos in the Arab world: God, sex and politics. ${ }^{11}$ A captivating storyteller, Aswany's characters sometimes wish that the Free Officers revolution never took place in 1952, given its horrible aftermath for most people. This is heresy talk for nationalist ears. Other characters indulge in human frailties; some explore the complexity of human sexuality, while the fascination with a theology of violence is portrayed in nuanced and believable terms. In very subtle literary locutions, Aswany reorganizes the sensible by introducing lines of fracture and disruption in the imaginary collective bodies of his subjects. Everywhere, those in power constantly fear that

10) http://tinyurl.com/6d3afyy

11) 'Alā' al-Aswānī, 'Imārat Ya qūbiyān : riwāyah (Cairo: Dār al-Shurūq, 2005). 
the power of words and the circulation of writing will produce disorder and disrupt the normal. For part of what literature and art do is to call into question the order and/or disorder of the political.

In an author's note to the Arabic edition of his novel, which is not available in the English edition, Aswany writes of the difficulties he had in publishing his work with the Egyptian Committee for Writers. ${ }^{12}$ The government sponsored Committee (thanks to a combination of factors, including political decadence and incompetence) refused to publish his work. The reason he was denied publication was that some of his characters criticize Egypt and Egyptian politics. A failure, laments Aswany, on the part of the guardians of Egypt's literary heritage to understand the difference between statement and narrative!

In the Yacoubian Building, Busayna, a poor female character, revealingly tells Zaki Bey, her bourgeois lover, of the daily grind that millions experience. "When you've stood for two hours at the bus stop or taken three different buses and had to go through hell every day just to get home," says Busayna, "when your house has collapsed and the government has left you sitting with your children in a tent on the street, when the police officer has insulted you and beaten you just because you're on a minibus at night ... then you'll know why we hate Egypt."13 Not until independent presses in Cairo and Beirut turned his book into an international bestseller did Aswany get recognition.

Aswany's portrayal of life in Egypt, as described in the words of Busayna, was also the life of Muhammad Bouazizi, the Tunisian street vendor. In despair, Bouazizi set himself alight in the central Tunisian town of Sidi Bouzid in December 2010, when the local government confiscated his license as a street vendor. The everyday life of people in the region became politicized by his act of self-immolation. This might be an extreme example of biopolitics - the control and elimination of undesirable bodies in circumstances where victims are forced to commit suicide. Giorgio Agamben, an Italian political philosopher would call this the politicization of "bare life" (zoẽ). Thanatopolitics - a politics of death - is the first principle of biopolitics; the threat or fear of death and, the calculated exercise of death. Here was an ordinary citizen denied a means of income; he was removed from effective participation in the civil order just as the damned or sacred man (homo sacer) in medieval times was

12) Ibid. 9-28

13) Alaa Al Aswany ('Alā’ al-Aswānī), The Yacoubian Building, trans. Humphrey T. Davies (Cairo ; New York: American University in Cairo Press, 2004), 138. 
excluded and killed with impunity. ${ }^{14}$ Deprived of a means of income, Bouazizi only executed what the state designed for him: deny him life, and strip him of his dignity. Thus in protest, he immolated himself, and his act became a suicide. But the homo sacer is normally one who gets killed without being sacrificed. In other words, the law of the land or the rules of religion outlaw human sacrifice. Yet, it is okay for the state to kill its citizens whenever it deems fit, or withdraws the means of income in the death-ridden schema of biopolitics. This is the complex and frightening irony of modern statecraft: while it tries to create a state of political existence (bios), it often leaves people with the single, stark choice of biopolitics.

Did Bouazizi, through his frightening act of suicide, reclaim his sovereignty? Normally, the sovereign is the one who says when and how the law is applicable, and when it is suspended-the sovereign is the one who declares a state of exception and makes political use of death. Bouazizi, in turn, took it upon himself to say that he could make a judgment on the worth of his life and therefore decided to commit suicide. In doing so he suspended the law prohibiting suicide in terms of both Islamic law and Tunisian secular law in the name of sovereign control. Re-claiming sovereignty in order to die is bewilderingly paradoxical. Bouazizi is a tragic sovereign, but his death drew attention to the inescapable side of the prevailing biopolitics of death in Tunisia and beyond.

However, there is another strange twist to the meaning of Bouazizi's death. Normally, the homo sacer gets killed but he does not become a sacrifice. His life does not serve any higher or transcendent purpose. Has Bouazizi become a sacrifice? I think he has. His act of tragic sovereignty set in motion a train of events that unzipped the sovereignty of the Tunisian state by delegitimizing the regime in control. Digitally, Bouazizi's image and name have gone viral, and in the Middle East (especially in Egypt) his death has been received in messianic tones. As a result of Bouazizi's death, a pre-existing Facebook page called, "All of us are Khalid Said" (saluting a victim of Egyptian police brutality several months' earlier), received new life. Now the Egyptian victim is memorialized as a homo sacer. In both countries, the uprisings have reclaimed the memories of both Bouazizi and Khalid Said in a less prominent sense of homo sacer, as holy personages and martyrs in a secular sense.

Many people have wondered what role religion played in Arab Spring uprisings. I am inclined to think that up to this point, these uprisings have the 
character of a secular religion, as my portrayal of the homo sacer suggests. Raymond Aron, in an illuminating essay, "The Future of Secular Religions", argues that even though secular political orders tend to be anti-religion, they also turn out to be like religion. ${ }^{15}$ In their secular guise, secular ideologies bring, in Raymond's words, "back to earth certain hopes that, in the past, were inspired by transcendental beliefs alone ... doctrines that in the souls of our contemporaries, take the place of the faith that is no more, placing the salvation of mankind in this world, in the more or less distant future, and in the form of a social order yet to be invented." ${ }^{16}$ If, in the past, the ideology of "the party" offered salvation to socialists, then one cannot ignore the faith that so many people in capitalist societies have invested in the talismanic power of social media, and for which the Arab Spring was held up as a poster boy. What Aron has written about ideologies could perhaps very well apply to our exaggerated faith in the salvation of social media, particularly in light of the following description that he ascribes to ideologies: "They demand sacrifices that bring immediate rewards; they rescue the individual from the loneliness of crowds without souls and life without hope." ${ }^{17}$ Accurate, yet devastating in its bathos.

In order for democracy to flourish in those countries recently divested of tyrants, only the old virtues of respect for the individual, for the mind and for personal autonomy hold out hope for a prosperous future. In my view, the regimes may have been de-centered, but they have yet to be displaced. The ghosts of Gamal Abdul Nasser in Egypt and Habib Bourguiba in Tunisia cultivated military virtues of action, self-discipline and dedication, but their wellintentioned plans quickly dissolved into tyrannies because they were not balanced by the old virtues. Such a scenario could well be replayed. Two major Islamic parties, the Renaissance Party in Tunisia and the Muslim Brotherhood in Egypt, are both strongly committed to military virtues, while the liberal virtues in their manifestoes are always qualified and capped by other countervailing considerations. This should be reason enough for serious concern, since these forces may become hegemonic through the ballot box.

The only antidote to such subversion is to ensure that the art and aesthetics of politics do not go on vacation, but continue to midwife new possibilities of the sensible. Continued vigilance to ensure that artists can express themselves

15) Raymond Aron, "The Future of Secular Religions," in The Dawn of Universal History: Selected Essays from a Witness of the Twentieth Century, ed. Yair Reiner, trans. Barbara Bray (New York: Basic Books, 2002), 177-201.

16) Ibid., 178.

17) Ibid., 179. 
and have the opportunity to remake the imagination with fiction and facts is one important aspect. Moreover, related to art and aesthetics is the need to keep alive a sense of the transcendent, beyond the immediate and the now. The devil's speech to Ivan Karamazov to avoid the worst impiety (i.e., to disregard everything outside the sphere of earthly existence) is edifying. "Man will identify himself with God and be filled with divine and Titanic pride. Sovereign lord of nature through knowledge and his own will, man will constantly experience such great satisfaction that it will replace all hopes of happiness hereafter." 18 Finally, let's hear Charles Baudelaire, who knows that after the 'Spring' come the seasons of work and labor in order to realize the new order:

Now are the autumn days of thought at hand.

And I must use the rake and the spade to groom,

Rebuild and cultivate the washed out land

The water had eroded deep as tombs. ${ }^{19}$

18) Fyodor Dostoyevsky, The Brothers Karamazov, trans. David Magarshack (Harmondsworth: Penguin, 1958), 735.

19) Charles Baudelaire, "The Enemy," in The Flowers of Evil, trans. James McGowan (Oxford \& New York: Oxford University Press, 2006), 29. 